\title{
大学地学教育と地質調査業*
}

\author{
岩松暉**
}

\section{Current University Education of Geology and Geological Consultants}

Akira IWAMATSU**

\section{1. 地学系学科卒業生の進路}

最近は大変景気がよい。毎年求人に訪れる人だけで 100 人に及ぶ。まさに嫁 1 人に婿 8 人である。青田刚り どころか，苗のうちから確保しようと奖学金まで出す会 社もある。ところが肝心の学生はなかなか就職したがら ない。世に言うモラトリアムである。しかもその就職先 が問題，地学科を出たのに地質関係の会社に行く人はご

*この資料は,「日本応用地質学会九州支部会報」No. 11 （1990）に掲載されたものを再録したものです。（編集委員 会）

** 鹿児島大学理学部地学教室 Institute of Earth Sciences, Faculty of Science, Kagoshima University
く僅かで，私の勤務する鹿児島大学で 2 割強でしかな い。これでは大変と, 国立19大学地学系教室主任会議 に提案して実態調査を行っていただいた。結果を見てあ ぜんとした。わが大学は良いほうなのである。最近 5 年間の平均で土木建設・資源素材といった地質関係の会 社に就職する率が 2 割を超えているのは秋田・山口・ 新潟・島根・鹿児島・琉球の 6 大学に過ぎない（図一 1: 富山大学は回答なし)。わが応用地質学会および業 界に直接かかわる土木建設系に就職する人が 2 割を超 すのは秋田・島根・鹿児島・新潟の 4 大学だけである。 全体では約 1 割で, その前の 5 年間が約 2 割だから半 減である(図-2)。これに反比例してコンピュータソ フト会社へ就職する人が倍増している。ソフト会社は地

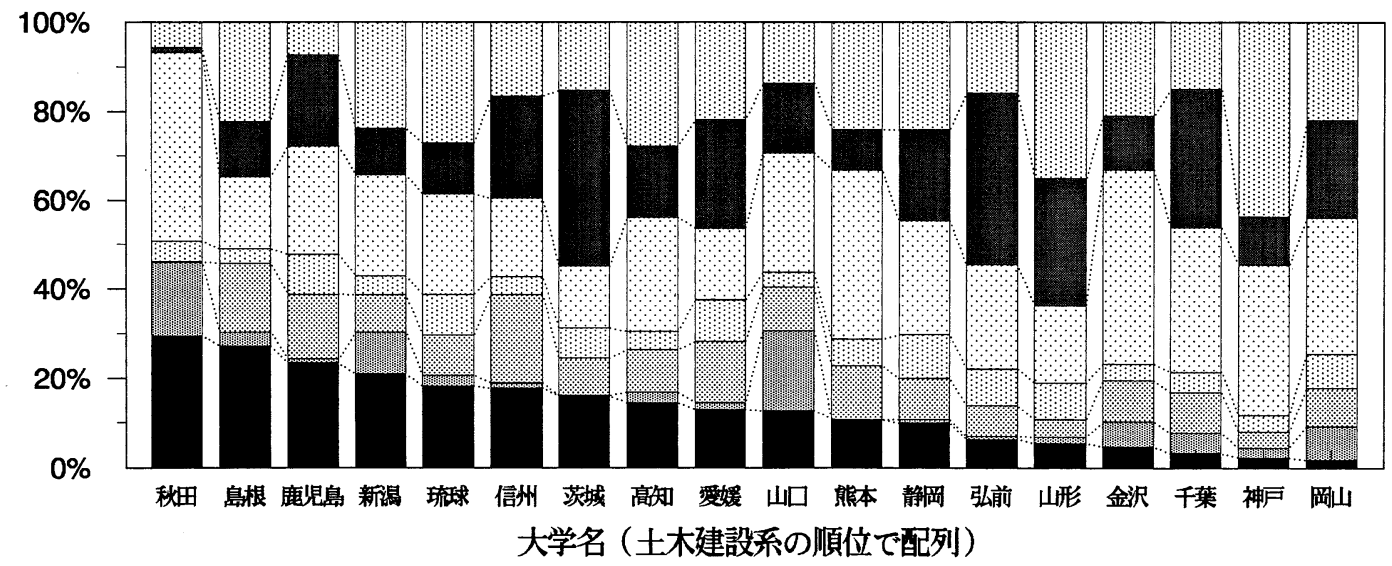

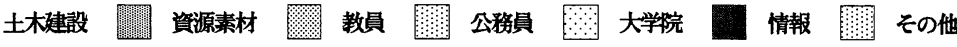

図-1 国立18大学地学系学科卒業生の進路（1984〜1988年度）〔国立19大学地学教室主任会議資料より作成。卒業生数ではな く, 進路の分野別比率による。] 




$1979 \sim 1983$ 年

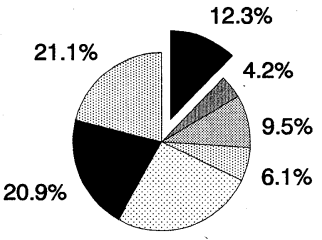

$25.9 \%$

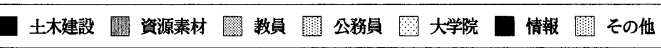

図 -2 過去10年間の就職先の変遷（1979 1988年度 $)$

質関係のソフトも作る場合があり，専門家としてシステ ムの構築に当たるのだから，専門を生かせる職場なので すと美辞麗句を並べるが，実際は数を充当するのに使わ れる使い捨てのコマなのであろう。学生も専門を生かす ためにソフト会社を選んでいるわけではない。

行政管理庁が1989年に秋田大学の監査を行った際, 卒業生名簿からランダムに特定個人を抜き出して, 専門 と無関係な職場に就職した理由を詰問した由, そんな学 科は税金のムダ遣いだから縮小廃止せよと言いたいので あろう。お役人的な短絡思考ではあるが，こうした面か らも地学科が外圧に曝されることは必至である。

こうなった理由はいろいろ考えられるが, 大学と産業 界双方に問題があるように思う。

\section{2. 教える側の問題点}

大変ショッキングな話を聞いた。先日ある地質コンサ ルの若い地質屋さんとフィールドを一緒に歩いたときの ことである。話が前述のような就職のことに及んだ。 「私の世代はそれほどでもなく, クラスの半数は地質コ ンサルに行きましたが, 問題がないわけではありませ ん」と,こんな話をしてくれた。

「地質コンサルに行ったクラスメート10数人のうち, 今でも地質をやっているのはその半数に過ぎません。あ との人は完全に地質々は無関係な仕事をしています。彼 等は学生時代, 岩石鑑定などはうまかったし, 地質が好 きでフィールドはよく歩いてすばらしい地質図を描きま した。総じて自分などより数等上でした。しかし，コン サルに入ってみると, あまりに土木的で彼等のイメージ にある地質学とは相当隔たっていますから，こんなはず じゃなかったと会社を辞めてしまうのです。生活の糧は 別な手段で稼いで，地質は趣味にとっておくのだそうで す。」

確かにハングリーでなくなったから，何をやってもメ シは食える。好きでも嫌いでも会社に自分を適合させて
いくしか生きる道のなかった時代とは違う。しかし，そ れだけと考えるよりもっと深刻な問題を投げかけてい る。すなわち, 大学における地質学教育の反省を迫って いると考えるべきではないだろうか。地質をやめて行っ た人たちは学生時代優等生だったのである。彼等が大学 で教わった地質学と実社会で日々活躍している地質学々 は全く異質だったから, 拒絶反応が出たのた。彼等の指 導教官の名前を聞いて，何となくうなずけた。要するに 象牙の塔のアカデミズムそのものである。こういう先生 に教わった学生が彼等なりに受け止めた地質学は, 少し 擬画化して言うと, ロマンに満ちた太古の昔の夢物語 か, 収集癖の好事家が化石を集めて喜んでいる麗しい趣 味の世界だったのであろう。土木地質学など地質学では ないのだ。科学の名に值しないと考えているに違いな い。中には「役に立たないことをやっているのを誇りに しているのが理学部だ」などと公言している先生もい る。こうした応用科学に対する無知・偏見は今に始った ことではない。地質工学の創始者渡邊 貫 (1952) は 純正科学と応用科学について, 次のように述べ悲憤慷慨 している。

『人工雪の研究で有名な北大教授中谷宇吉郎博士が, かつて筆者に次のような忍澫を漏らしたことがあった。 “大学や研究所で実用方面への応用に力をつくすと学者 があたかも䏣落したようにいう人がある。実用目的があ ってこそ始めて学問の研究に拍車がかけられるのであっ て, 単なる象牙の塔での孤独な存在は人生において無意 義である”と。

筆者もこの点同感であって，かつて有島武郎が云った ように, “それが単なるカード・ボックスの整理にすぎ ないような仕事でも, そのことがたまたま大学構内の片 隅で行われているということだけで，それを学問と云っ たり学者としたりすることは間違っている。学問とは, 学者とは, 何等かの方法によって人生に光明を与えるも のでなければならぬ”。

Academic fool という言葉があるが，わが国の大学人 種の中に往々にしてこの種の人間がおり, 理科系の学者 が実用方面に赴くのをあたかも学問の陏落の如く考えて いる愚者がいる。』

こうした Academic fool は，何もお年寄りのクラシッ クな学者先生に見られるだけではない。ここ 20 年来, 地質学と社会の接点であった資源産業が衰退して地質学 が実社会から切り離されたところへ, プレートテクトニ クスのようなフィールドでなかなか検証しにくい学説が 導入され，思弁的な学風が支配的になってきた。その 上, 博士失業などが深刻となり，自ら視野を狭めて狭い 
領域の専門家として早く名を成す必要に迫られたため, たこつぼ型の若手研究者が大量に養成されている。この ような人たちが教育に当る時代になったのだから, “か っこいい学問にあこがれる”学生が育つのは当然であ る。

こうした応用科学軽視の風潮と同時に, 純粋地質学自 体が活気を失い, 若者にとって魅力が薄れているのも, いまひとつやる気を起こせない原因になっていると思 う。世間一般では地球科学う地球物理学と考えられてお り, 地質学の影は薄い。プレートテクトニクスの壮大な 仮説にしても, 地球物理学が生み出してきたものであ り, 地質学の本質的な貢献は少ない。1989年春は測地 学審議会が「地球科学の推進について」と題する建議を 行った。当然のことながら地球物理学を柱とするビック プロジェクトが推進課題とされている。地質学は添え物 扱いである。今後この建議に沿った学科改組の嵐が大学 に吹き荒れるに違いない。しかし, 地球物理学のほうが 何時も地質学をリードしていたわけではない。戦前, 資 源産業が華やかだった頃は, 地質学のほうがはるかに革 新の息吹に満ち活気があったが，一方地球物理学は寺田 寅彦の随筆に見られるように高踏的サロン的であった。 やはり, 近年地震予知計画など地球物理学が社会のニー ズに積極的に応える姿勢に立ったとき，急速に発展して きたと言える。これに反し，地質学は実社会から遊離 し, 趣味的博物学的方向に, いわば先祖返りしている。 純粋科学と応用科学は車の両輪であり, 両々相俟って発 展するのである。地質学を 1 本の樹にたとえれば, 社 会という大地にしっかりと根を下ろし, 養分を吸収して いる太い幹が応用地質学であり, その上に緑豊かに繁っ ている葉が純粋地質学である（図一3）。根や幹がなけ れば葉は存在し得ないし, 葉が繁り日光（物理・化学な どの関連諸科学）の恵みを得て大いに光合成を行わなけ れば, 幹も大きくなれないのである。今の日本の地質学 は，根が貧弱で萎れている樹にたとえられよう。

もう 1 つ, 地質の好きな学生が土木地質に違和感を 持つ理由に, 数字に還元して考える発想が身についてい ないこともあるように思う。もともと地学科に進学して くる学生は, 数学・物理が弱い（鹿児島県の場合, 高校 では理系クラスは物理・化学必修で, 地学は文系しか選 択できない由)。しかもフィールドの好きな（フィール ドしかできない?）層序学関係の学生ほど極端に弱い。 しかし現場では, c·申だ, 切土勾配だと数字がたくさん 出てくる。どうもそれでアレルギーを起こしているらし い。こうした地質屋的地質屋が書いた報告書は, 岩石の 顕微鏡写真まで付いて地質の記載はやたら詳しいが，設

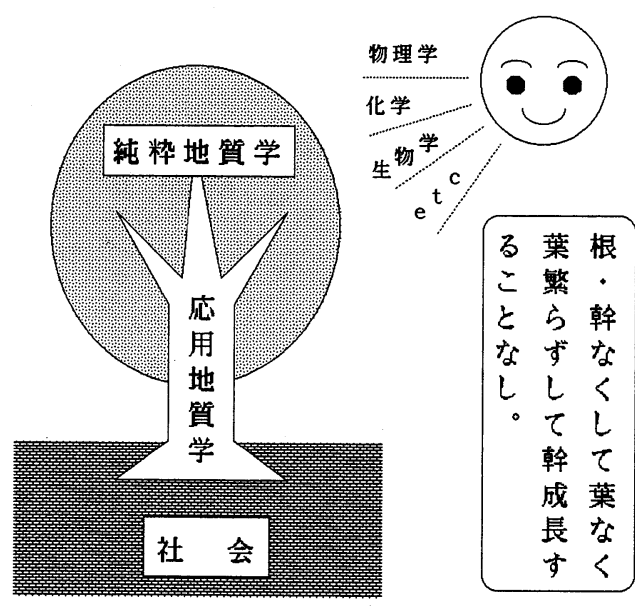

図-3 応用地質学と純粋地犋学

計施工に必要不可欠な肝心のデータがないと，建設コン サルやゼネコンからは不評を買う。当然上役から叱られ る。当人は大学なら誉められるようなすばらしいレポー トを書いたのにと不満が繿積する。それで辞める人もい るらしいのである。確かに地質学は総合科学ではある が，大きく見ればやはり physical science の中の 1 分科 であることが忘れられている。もっと数理的な教育を強 化しなければならない。

\section{3. 学ぶ側の問題点}

学生気質の变化も著しい。まず何よりも地学科に入学 してくる者には不本意入学者が多い。昔は山や自然が好 きだといったそれなりの志望理由があったが，共通一次 試験発足以来, 入りたい大学より入れる大学, コンピュ 一タが偏差值で選んでくれた第 1 志望なのである。し たがって，かつては山岳部やワンゲル・ラグビー部など 身体を動かす運動部に入る学生が多かったが，今は極端 に少ない。基礎体力づくりのためにハードトレーニング を強制される “部”よりも, ゲームを楽しむ “同好会” やガールハントの “愛好会”が花盛りである。また, 受 験競争の激化に伴い, 幼時から塾だ家庭教師だと勉強し ないと国立大学に入れなくなったから, 都会の進学校出 身者がほとんどで, 郡部出身は稀になってしまった。自 然の中でどろんこになって遊んだ経験がないのである。 したがって, 山を歩く楽しみどころか, フィールド調査 などは苦役以外の何ものでもない。

もちろん, 社会の変化が学生気質に深く反映している のは当然である。戦後の混乱期以来, 食える生活, より よい生活を夢見て，ともかく遮二無二働いてきた。今日 の日本の繁栄はこうした “仕事人間”, “もうれつ社員” 
が築いてきたのである。しかし，高度成長から一転して 低成長, 出世も先が見えている。しかも狂乱地価で一生 働いても家一軒買えない。「どうせ努力しても所詮…」 と極めて冷めており, “無気力症候群”などという言葉 がはやって久しい。それにほとんどが 1 人っ子か, せ いぜい 2 人, 両親の溺愛と期待を一身に集め, 地球は 自分を中心に回転してきたから，幼児性・自己中心性の 抜けきらないまま大人になってしまった。当然, 他者に 対する思いやりはなく，額に汗することを厭う。また，

管理主義教育の徹底で何事も受け身，命令しなければな らないし，命令したことしかやらない。しかも飽食の時 代で, かつ, 求人難の時代, 遊んでいても適当にメシは 食える。レジャ一資金さえ手に入れば, フリーアルバイ ターのほうが気楽でよい。土木建設は, “きつい・きた ない・きけん”の $3 \mathrm{~K}$ と言われて敬遠されるのは当然で ある。

\section{4. 受け入れる側の問題点}

学生を受け入れる業界のほうにも問題がある。地質コ ンサルタントに就職した若い先輩が母校に遊びに来たと き, 後輩たちに胸を張って誇らしげに仕事を語る人は皆 無に近い。いわく,

(○出張が年間100日を越す。赤ん坊に顔を忘れられ，人 見知りされて泣き出されてしまった。

(○毎日のように10時，11時まで残業で，しかも残業手 当がまともに出ず，大部分ただ働き，日曜出勤もしば しば，過労死もひとごとではない。週休 2 日は夢の また夢。

○労使関係が前近代的で, 家族的と言えば聞こえがよい が，要するに封建的なしがらみで一方的に奉仕させら れる。

○他の職種に就職した同級生より月給が確実に 1 万円 は低い。使っているアルバイターのほうが手取りがよ い。

○同じ安いのなら公務員みたいに威張りたい。日本はか つての東欧以上に官僚国家, 生殺与奪の権を握ってい るから，お役人の前ではぺこぺこしなければならな い。実力があるならまだしも, 素人のくせに威張る奴 がいる。

○神様, 仏様, お施主様, いつもゼネコンの顔色をうか がわなければならない。

○いくつもの現場を掛け持ちさせられ, 良心的な仕事が できない。勉強して技術を向上させる暇もない。 などなど……思痴が口を突いて次から次へと出てく る。まさに $3 \mathrm{~K}$ そのものか, それ以上。当然, 後輩たち
はその会社には絶対に行かない。それだけでなく，地質 調査業そのものを敬遠する。

ぜひ若手が意気揚々として後輩たちに語ることのでき る，魅力ある業界にしてもらいたい。いつも転職のこと が念頭にあるようでは困る。“鬼小屋に住む働き蜂”の 時代は確実に過ぎ去っている。良きにつけ悪しきにつ け，新人類が社会に進出する時代になったのである。彼 らの「人間らしい，ゆとりのある生活がしたい」という 要求にこたえることは国際批判にこたえることでもあ る。仕事＝生きがい論だけでは済まない。同時に，新人 類の持つ積極面を正当に評価し，それを取り入れる姿勢 と施策が求められていると言えよう。一考を促したい。

根本的には地質屋の社会的地位の向上をはかることが 第一である。欧米では geologist の社会的地位はたいへ ん高いという。わが国では, 同じコンサルタントなの に, 弁護士は社会的に尊敬され名士扱いされるが, 普通 はコンサルティングそのものに対する評価が低い。富士 通の図書館管理システム 1 円受注事件がそれを象徵し ている。役所やゼネコンの仕様書通りに調査するだけで なく, 欧米の geologiist のように土木工事全体に発言権 を持つ重みのある存在になりたいものである。土木屋か ら一目置かれるような, 真に “使える応用地質学”を創 造していくことが基本だが, 抢役所の積算システムなど も改善する必要があろう。1989年建設コンサルタント 中長期ビジョンが出された。ATI 構想と銘打たれ,「魅 力に满ち (Attractive)，技術を競う（Technologically spirited), 独立した (Independent) 知的産業を目指し て」いる。この構想の早期実現を切望する。

\section{5.おわりに}

問題点と題したので, かなり否定的な側面を強調し過 ぎたきらいがある。例えば新人類にしても，われわれの 世代にない優れた感性を持っており，興味を抱いたこと には結構頑張る。自己中心的と述べたが, ボランティア 活動などを一生懸命やる者もいるのである。

現状を単に嘆いているだけでなく，21世紀の飛躍を 実現しうる土台を，この残された 10 年のうちに築いて いかなければならない。幸いこの応用地質学会は産・官 ・学の 3 者が対等に参加している場である。大いに協 力の実を挙げ，この課題をやりとげたいものである。

\section{参考文献}

渡邊 貫 (1952)：地質工学の現在及び将来, 地質工学, 1 輯, pp. 1-4. 